\title{
KEMANDIRIAN BELAJAR SISWA KELAS III SDN KARANG JALAK I DALAM PEMBELAJARAN TEMATIK
}

\section{INDEPENDENCE OF LEARNING ON THIRD GRADE STUDENTS SDN KARANG JALAK I IN THEMATIC LEARNING}

\author{
Fety Tresnaningsih ${ }^{1}$, Dina Pratiwi Dwi Santi ${ }^{2}$, Etty Suminarsih $^{3}$ \\ ${ }^{1}$ PGSD, FKIP, Universitas Swadaya Gunung Jati \\ ${ }^{2}$ PGSD, FKIP, Universitas Swadaya Gunung Jati \\ ${ }^{3}$ SDN Karang Jalak I \\ ${ }^{1}$ feytresna04@gmail.com, ${ }^{2}$ dinapratiwids@ fkip-unswagati.ac.id, ${ }^{3}$ ettynarsih@ gmail.com
}
Pengutipan: Tresnaningsih, F., Santi, D. P. D., \& Suminarsih, E. (2019). Kemandirian belajar siswa Kelas III SDN Karang Jalak I dalam pembelajaran tematik. Pedagogi: Jurnal Penelitian Pendidikan, 6(2), hlm 51-59

Diajukan: 18-12-2019

Diterima: 30-12-2019

Diterbitkan: 31-12-2019

\begin{abstract}
ABSTRAK
Kemandirian belajar diperlukan bagi manusia sepanjang hidupnya. Namun, siswa belum memiliki kemandirian secara optimal dalam belajar. Penelitian ini bertujuan untuk mengetahui kemandirian belajar siswa kelas III SDN Karang Jalak 1 dalam pembelajaran tematik. Pendekatan yang digunakan dalam penelitian ini adalah kualitatif dengan jenis penelitian yaitu deskriptif. Teknik pengumpulan data menggunakan observasi dan dilakukan dengan metode kuesioner atau angket kemudian menggunakan skala likert. Subjek penelitian adalah siswa kelas III SDN Karang Jalak I. Bentuk kemandirian belajar siswa yang dikembangkan di SDN karang Jalak 1 di antaranya percaya diri, aktif dalam belajar, disiplin, memiliki hasrat untuk maju, mampu bekerja sendiri, tanggung jawab, dan mampu mengambil keputusan. Berdasarkan hasil penelitian dapat disimpulkan bahwa kemandirian belajar siswa kelas III di SDN Karang Jalak 1 berkembang dengan baik dan sangat antusias sehingga interaksi proses belajar mengajar dapat berlangsung sesuai yang diharapkan.
\end{abstract}

Kata Kunci: kemandiran belajar; siswa; pembelajaran tematik

\section{ABSTRACT}

Learning Independence is needed for humans throughout their lives. However, students do not have optimal independence in learning. This study aims to determine the learning independence of class III students at SDN Karang Jalak 1 in thematic learning. The approach used in this research is qualitative with the type of research is descriptive. Data collection techniques using observation and carried out by a questionnaire using a Likert scale. The form of student learning independence developed at SDN Karang Jalak 1 includes confidence, being active in learning, being disciplined, having a desire to progress, being able to work alone, being responsible, and being able to make decisions. Based on the results of the study it can be concluded that the independence of learning of third grade students at SDN Karang Jalak 1 is developing well, unless the indicator is able to take decisions into the criteria quite well.

Keywords: independence of learning; studen; thematic learning 
Fety Tresnaningsih, Dina Pratiwi Dwi Santi, Etty Suminarsih

KEMANDIRIAN BELAJAR SISWA KELAS III SDN KARANG JALAK I DALAM

PEMBELAJARAN TEMATIK

\section{PENDAHULUAN}

Pendidikan merupakan usaha sadar dan terencana untuk mewujudkan suasana belajar dan proses pembelajaran agar siswa secara aktif mengembangkan potensi dirinya untuk memiliki kekuatan spiritual keagamaan, pengendalian diri, kepribadian, kecerdasan akhlak mulia, serta keterampilan yang diperlukan dirinya, masyarakat, bangsa dan Negara. Sedangkan guru adalah orang pertama dalam meningkatkan mutu pendidikan. Berkaitan dengan kemandirian belajar, yang berperan membentuk sikap mandiri adalah guru. Sebagaimana hasil penelitian Tasaik, H. L., \& Tuasikal, P. (2018) yang menunjukkan bahwa guru sangat berperan penting dalam membina dan membentuk sikap kemandirian dalam proses pembelajaran. Dengan kata lain, dalam proses pembelajaran setiap siswa selalu diarahkan agar menjadi siswa yang mandiri. Hal ini dikarenakan mandiri sangat berpengaruh penting dalam tumbuh kembang anak.

Sa'diyah (2017: 16) menyatakan anak yang memiliki kemandirian dalam kegiatan belajar akan terlihat aktif, menguasai strategi-strategi dalam belajar dan mampu mengatur perilaku kondisinya serta memiliki keyakinan diri. Kemandirian berasal dari kata mandiri yang berarti berdiri sendiri. Asrori Ali (Suid \& Syafrina, 2017) menyatakan kemandirian merupakan suatu kekuatan internal yang diperoleh melalui proses realisasi kemandirian dan proses menuju kesempurnaan.

Kemandirian belajar merupakan salah satu faktor yang menentukan keberhasilan siswa dalam belajar. Menurut Rahmawati, D. (2016) ada pengaruh antara kemandirian belajar dengan hasil belajar. Dengan demikian, diperlukan sikap mandiri untuk mencapai kesuksesan dalam hidupnya. Apabila seorang siswa memiliki kemandirian belajar yang baik maka mereka sudah memilih jalan yang benar sebagai bentuk tanggung jawab seorang pelajar.

Berdasarkan hasil temuan di lapangan siswa kelas III SDN Karang Jalak I melalui pengamatan yang dilakukan, Siswa masih belum memiliki nilai kemandirian dalam pembelajaran. Hal ini dapat dilihat dari permasalahan yang terjadi diantaranya adalah siswa tidak yakin pada kemampuan diri sendiri, siswa minta diarahkan guru secara terus menerus dalam kegiatan belajar, siswa membutuhkan orang lain dalam menyelesaikan masalahnya sendiri, tidak mampu belajar sendiri, siswa sering menyontek, dan siswa menggunakan waktu belajar di sekolah hanya untuk bermain pada saat jam kosong. Siswa yang kurang memiliki kemandirian dalam belajar mereka akan malu dan takut mengungkapkan pendapat nya dan dalam menyelesaikan tugas masalahnya mereka cenderung bergantung kepada orang lain. Menurut Salina (2013:77) siswa yang tidak mandiri akan merugikan dirinya sendiri karena belum mampu dalam memecahkan masalah yang dihadapi dan memiliki rasa percaya diri yang lemah.

Menurut Fatimah (2006) proses kemandirian belajar dapat dikembangkan melalui latihan-latihan yang dilakukan secara terus menerus dan dilakukan sejak dini, latihan berupa pemberian tugas-tugas tanpa bantuan. Selain itu, menumbuhkan kemandirian belajar dapat dilakukan dengan memotivasi dan membuat perencanaan mata pelajaran (Bakhtiar, B., 2017). Kemandirian juga dapat dikembangkan dalam pembelajaran melalui lesson study seperti yang dilakukan oleh Mina, W., \& Vitoria, L. (2017). Hasil dari penelitiannya menunjukkan bahwa siswa kelas V SDN Lampegeu Aceh Besar sangat antusis dan bersemangat, sehingga interaksi proses belajar mengajar dapat berlangsung seperti yang diharapkan.

Menurut Desmita (2009), Kemandirian belajar terdiri dari tujuh aspek/kategori yaitu percaya diri, mampu bekerja sendiri, mampu mengambil keputusan, bertanggung jawab, hasrat bersaing untuk maju, disiplin, dan aktif dalam belajar belajar mandiri diciptakan oleh guru cara menumbuhkan keterkaitan siswa dengan yang diajarkan sehingga memabntu siiswa dalam kegiatan belajar. Teori belajar Humanisme adalah teori yang menghubungkan antara kemandirian belajar siswa dengan hasil belajar yang di dapat siswa. 
Berdasarkan permasalahan di atas, peneliti tertarik untuk melakukan penelitian mengenai "Kemandirian Belajar Siswa Kelas III SDN Karang Jalak I dalam Pembelajaran Tematik", yang bertujuan untuk mengetahui bagaimana kemandirian belajar yang dimiliki oleh siswa kelas III SDN Karang Jalak I dalam pembelajaran tematik.

\section{METODE PENELITIAN \\ Jenis Penelitian}

Penelitian ini menggunakan pendekatan kualitatif dengan jenis penelitian deskriptif. Menurut Sugiyono (2011) metode pengumpulan data dalam penelitian kualitatif secara umum dikelompokkan ke dalam dua jenis cara, yaitu teknik yang bersifat interaktif yang meliputi wawancara dan observasi sedangkan metode kualitatif noninterktif meliputi teknik kuesioner, mencatat dokumen, dan partisipasi tidak berperan. Metode kualitatif sebagai prosedur penelitian yang menghasilkan data deskriptif berupa kata-kata tertulis atau lisan dari perilaku yang dapat diamati. Alasan digunakannya jenis penelitian ini adalah karena peneliti ingin mengetahui dan memberikan gambaran secara jelas, detail dan konkrit kemandirian belajar siswa pada pembelajaran tematik kelas III. Penelitian deskriptif yaitu pengumpulan data berdasarkan faktor-faktor yang menjadi pendukung terhadap objek penelitian (Arikunto, 2014: 151). Sedangkan penelitian kualitatif adalah data yang berbentuk kata, skema, dan gambar (Sugiyono, 2011: 14).

\section{Waktu, Tempat, Sasaran, dan Subjek Penelitian}

Penelitian ini dilakukan pada semester ganjil tahun ajaran 2019/2020 di SDN Karang Jalak 1 Kota Cirebon dengan subjek penelitian adalah siswa kelas III. Adapun sasaran penelitian ini adalah kemandirian belajar yang dimiliki oleh mereka.

\section{Prosedur dan Teknik Pengumpulan Data}

Menurut Sugiyono (2015) teknik pengumpulan data merupakan langkah paling strategis dalam penelitian karena tujuan utama penelitian adalah mendapatkan data. Teknik pengumpulan data yang dilakukan peneliti untuk mengetahui kemandirian belajar siswa dengan observasi (pengamatan) dan angket. Observasi dilakukan kepada siswa untuk melihat kemnadirian belajar siswa dari indikator kemandirian belajar di SDN Karang Jalak 1.

Angket (kuesioner) merupakan teknik pengumpulan data yang dilakukukan dengan cara memberi seperangkat pernyataan kepada responden untuk dijawabnya (Sugiono, 2014: 199200). Angket yang digunakan dalam penelitian ini berupa angket tertutup, dengan jumlah pernyataan sebanyak 27. Langkah menyusun kisi-kisi dengan mendefinisikan secara operasional variabel-variabel yang akan diteliti, kemudian masing-masing variabel dijabarkan dalam indikator-indikator yang ditunjukan dengan 27 pernyataan dari semua indikator.

Tabel 1. Kisi-kisi Kemandirian Belajar

\begin{tabular}{lcl}
\hline \multicolumn{1}{c}{ Variabel } & Indikator & \multicolumn{1}{c}{ Aspek yang Diamati } \\
\hline Kemandirian & 1. Percaya Diri & 1.1 berani tampil dimuka umum \\
Belajar & & 1.2 percaya kepada kemampuan diri sendiri \\
& & 1.3 berani bertanya \\
& & 1.4 berani mengemukakan pendapat \\
& & 1.5 berbicara lancar saat berada dihadapan orang banyak \\
& & 1.6 bersemangat mengikuti diskusi kelompok \\
& & 1.7 bersikap tenang dalam mengerjakan segala sesuatu \\
& & 1.8 berusaha mengerjakan tugas sendiri \\
& 2. Mampu & 2.1 melakukan tugas tanpa diperintah orang lain \\
\hline
\end{tabular}


Fety Tresnaningsih, Dina Pratiwi Dwi Santi, Etty Suminarsih

KEMANDIRIAN BELAJAR SISWA KELAS III SDN KARANG JALAK I DALAM

PEMBELAJARAN TEMATIK

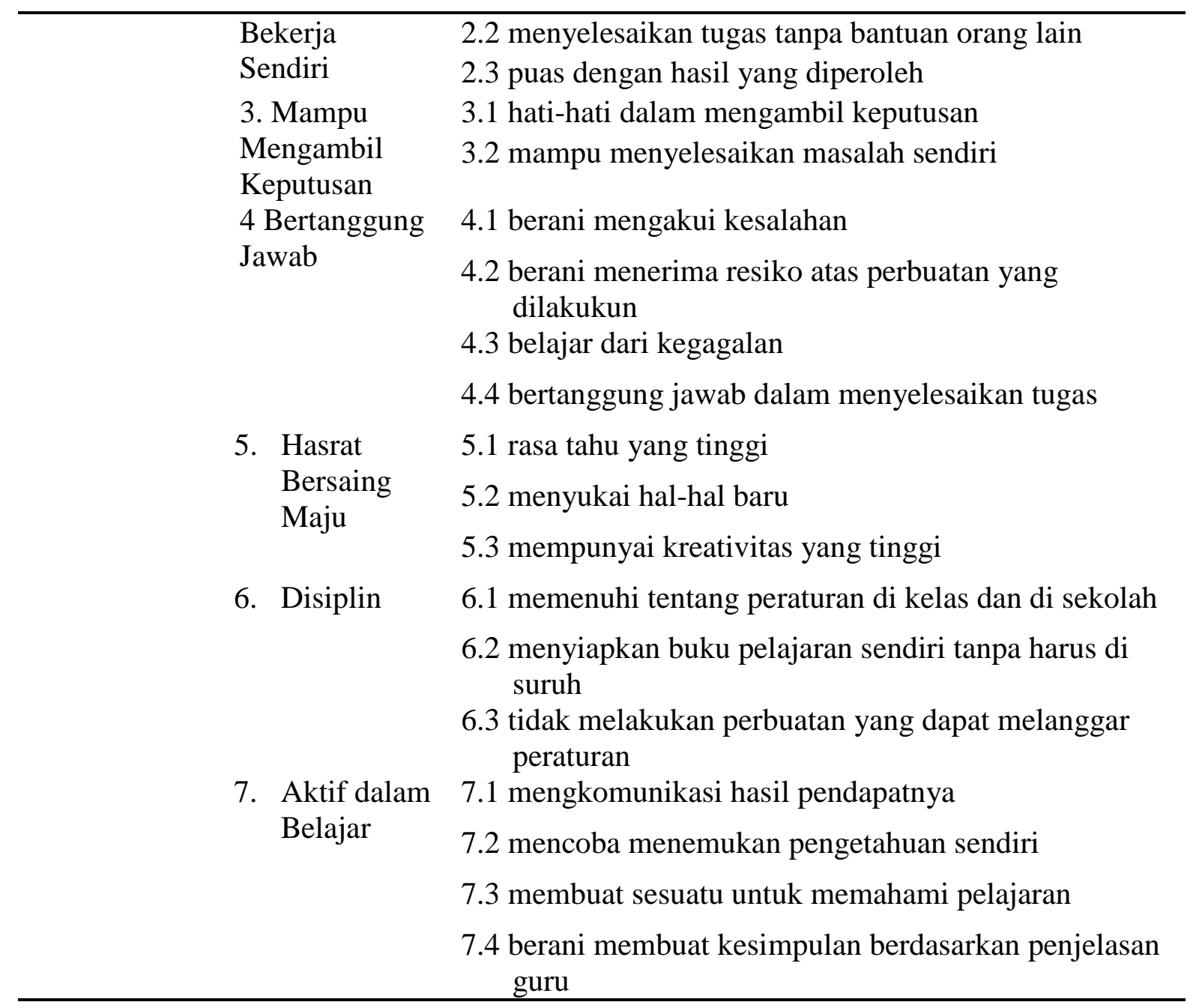

\section{Teknik Analisis Data}

Data yang diperoleh dari hasil angket masih merupakan data-data mentah apabila belum diolah. Agar data tersebut memiliki arti, dilakukanlah data pengolahan data dengan melakukan teknik dan langkah-langkah di antaranya mengoreksi data yang ada yang terkumpul penelitian angket, mengklasifikasi data bertujuan untuk memperoleh gambaran atas jawaban yang terdapat pada setiap pertanyaan yang diberikan kepada sampel dan menganalisis data kemandirian belajar siswa dengan menggunakan skala likert

Menurut Sugiono (Setyo,2017) skala likert merupakan metode pengukuran yang digunakan untuk mengukur sikap, pendapat seseorang atau kelompok. Scoring merupakan langkah pemberian skor atau langkah memberikan kategori untuk setiap butir jawaban dari responden dalam angket Sugiyono (Setyo,2017). Skoring yang digunakan dalam pengolahan ini sebagai berikut.

Tabel 2. Skoring Kuesioner Kemandirian Belajar

\begin{tabular}{cc}
\hline KRITERIA & Skor \\
\hline Selalu & 4 \\
Sering & 3 \\
Jarang & 2 \\
Tidak Pernah & 1 \\
\hline
\end{tabular}


Sedangkan untuk mengetahui jumlah jawaban dari para responden melalui persentase, yaitu digunakan rumus sebagai berikut.

Keterangan :

$$
\mathrm{P}=\frac{f}{n} \times 100 \%
$$

$\mathrm{P} \quad$ : presentase

f : frekuensi dari setiap jawaban angket

n : jumlah skor ideal

100 : bilangan tetap

Selanjutnya skor yang telah diperoleh kemudian dimasukan ke dalam rating scale. Rating scale berfungsi untuk mengetahui hasil data angket (kuisioner) dengan ketentuan sebagai berikut.

Tabel 3. Kategori Persentase Nilai

\begin{tabular}{ll}
\hline Nilai jawaban & Skala/Kriteria \\
\hline $\mathbf{8 1}-\mathbf{1 0 0}$ & Sangat Baik \\
$\mathbf{6 1}-\mathbf{8 0}$ & Baik \\
$\mathbf{4 1}-\mathbf{6 0}$ & Cukup Baik \\
$\mathbf{2 1}-\mathbf{4 0}$ & Kurang Baik \\
$\mathbf{0}-\mathbf{2 0}$ & Sangat Kurang Baik \\
\hline
\end{tabular}

\section{HASIL PENELITIAN DAN PEMBAHASAN}

Berdasarkan hasil observasi data kemandirian belajar siswa pada kamis, 05 September 2019 direduksi sesuai dengan kategori kemandirian belajar sebagai berikut.

Dalam kategori percaya diri seluruh siswa kembali duduk di karpet dengan tertib. Sesuai dengan indikator pencapaian percaya diri yaitu bersikap tenang di dalam mengerjakan segala sesuatu. Dengan percaya diri, siswa $\mathrm{C}$ menunjuk tangan untuk membacakan teks tersebut. Sesuai dengan indikator pencapaian percaya diri yaitu mempunyai potensi dan kemampuan yang memadai. Siswa B mengacungkan tangannya untuk memberikan pendapatnya mengenai makna atau arti dari kata yang teman-temannya belum pahami. Sesuai dengan indikator pencapaian percaya diri yaitu memiliki kecerdasan yang cukup.

Dalam kategori Aktif dalam belajar siswa berdiskusi mengenai contoh nyata di kehidupan mereka. Sesuai dengan indikator pencapaian aktif dalam belajar yaitu siswa Sesuai dengan indikator pencapaian aktif dalam belajar yaitu pengetahuan di pelajari, dialami dan ditemukan oleh siswa. Setiap kelompok maju menyampaikan hasil diskusinya. Sesuai dengan indikator pencapaian aktif dalam belajar yaitu siswa mengkomunikasikan hasil pikirannya. Dalam kategori mampu bekerja sendiri siswa berdiskusi agar siswa dapat mandiri dan menemukan sendiri materi yang akan dipelajari, guru hanya mengarahkan dan memperkuat sehingga siswa dapat dengan mudah menyerap pengetahuan.

Dalam kategori Disiplin dalam belajar seluruh siswa dengan sigap dan mandiri menyiapkan peralatan belajar. Sesuai dengan indikator pencapaian disiplin dalam belajar yaitu semangat dan antusias dalam kegiatan pembelajaran. Siswa Z, S dan F mengacungkan tangannya secara bergantian menanyakan kata yang mereka belum pahami. Sesuai dengan indikator pencapaian disiplin dalam belajar yaitu mengatasi kesulitan yang timbul pada dirinya. Siswa A maju ke depan kelas untuk memimpin do'a pulang. Sesuai dengan indikator pencapaian disiplin dalam belajar yaitu bertanggung jawab terhadap tugas piket yang diberikan.

Dalam kategori Tanggung Jawab dalam belajar seluruh siswa selesai membacaan teks tentang manfaat tumbuhan bagi kehidupan manusia. Sesuai dengan indikator pencapaian tanggung jawab dalam belajar yaitu memiliki komitmen yang tinggi terhadap tugas dan 
Fety Tresnaningsih, Dina Pratiwi Dwi Santi, Etty Suminarsih

KEMANDIRIAN BELAJAR SISWA KELAS III SDN KARANG JALAK I DALAM

PEMBELAJARAN TEMATIK

pekerjaannya. Hasil pengamatan dalam proses pembelajaran yang berlangsung dengan hasil kuesioner tidak jauh berbeda. Hal ini tampak dari hasil penelitian kuesioner yang disajikan dalam tabel dibawah ini.

Tabel 4. Hasil Angket Kemandirian Belajar

\begin{tabular}{clcc}
\hline No & \multicolumn{1}{c}{ Indikator } & Skor & Kriteria \\
\hline $\mathbf{1}$ & Percaya diri & 75 & Baik \\
$\mathbf{2}$ & Mampu bekerja sendiri & 75 & Baik \\
$\mathbf{3}$ & Mampu mengambil keputusan & 50 & Cukup Baik \\
$\mathbf{4}$ & Bertanggung jawab & 75 & Baik \\
$\mathbf{5}$ & Hasrat bersaing maju & 66 & Baik \\
$\mathbf{6}$ & Disiplin & 75 & Baik \\
$\mathbf{7}$ & Aktif dalam belajar & 62,5 & Baik \\
& Rata-rata & 68,3 & Baik \\
\hline
\end{tabular}

Berdasarkan di atas, diperoleh hasil rata-rata 68,3 berarti telah terbentuk kemandirian belajar siswa dengan kriteria baik. Pada indikator percaya diri diperoleh skor 75 dengan kriteria baik. Menurut hakim (2014) seseorang yang mempunyai rasa percaya diri lebih, ia merasa yakin dengan kemampuannya sendiri sehingga dapat dilihat tingginya kemandirian, hubungan sosial, tanggung jawab serta harga dirinya. Pada indikator mampu bekerja sendiri diperoleh skor 75 dengan kriteria baik. Manusia sebagai mahluk sosial tidak dapat hidup sendiri, tentunya membutuhkan orang lain dalam menjalankan kehidupan ini. Menurut Uno (2006:77) mengartikan kemandirian sebagai kemampuan untuk mengarahkan dan mengendalikan diri dalam berpikir dan bertindak, serta tidak merasa bergantung pada orang lain secara emosional. Pada intinya, orang yang mandiri itu mampu bekerja sendiri dan tidak bergantung kepada orang lain.

Pada kategori mampu mengambil keputusan dari perhitungan menunjukan skor nilai yang diperoleh 50 dengan kriteria baik. Dalam kehidupan sehari-hari orang tidak terlepas dari berbagai masalah yang harus diselesaikan dengan baik. Menurut Suid (2017) seorang siswa yang memiliki kemandirian belajar harus mampu mengambil keputusan dengan bijaksana serta selalu mempunyai inisiatif untuk memecahkan masalah yang dihadapinya. Hal ini akan menuju proses dalam kemandirian. Pada indikator bertanggung jawab dari perhitungan menunjukan skor nilai yang diperoleh 75 berada pada kriteria baik. Menurut Bunandar (2016) mengungkapkan ciri-ciri orang yang memiliki sifat tanggung jawab sebagai berikut : 1) Berorientasi ke masa depan, 2) Memiliki komitmen yang tinggi terhadap tugas atau pekerjaannya, 3) Mau belajar kegagalan, 4) Kemampuan memimpin dan yakin pada dirinya. Dengan terbentuknya tanggung jawab siswa, dapat membantu meningkatkan motivasi belajar serta kemampuan kognitif peserta didik, sehingga dapat dijadikan solusi untuk memperbaiki kesuksesan hasil belajar.

Pada kategori hasrat bersaing maju dari perhitungan menunjukan skor yang diperoleh 66 pada kriteria baik. Anak yang memiliki sikap yang tidak mudah patah semangat dalam menghadapi berbagai rintangan, selalu bekerja keras untuk mewujudkan suatu tujuan semua itu demi kebaikan dirinya sendiri. Kemauan dan hasrat untuk selalu ingin maju agar mencapai 
apa yang diinginkan sejalan dengan pendapat suryo (2008) orang yang mandiri memiliki ciriciri memiliki hasrat bersaing maju. Pada kategori disiplin dari perhitungan menunjukan skor yang diperoleh 75 berada pada kriteria baik. Dalam data catatan di lapangan juga aktivitas siswa mengenai kemandirian belajar telah sesuai dengan indikator pencapain disiplin belajar. Menurut Mudjiman (Isnawati,2015) disiplin siswa pada proses pembelajaran dapat di amati berdasarkan lima aspek yaitu: bertanggung jawab terhadap tugas yang diberikan, semangat dan antusias dalam pembelajaran, komitmen yang tinggi terhadap tugas, mengatasi kesulitan yang timbul pada dirinya dan kemampuan memimpin. Menurut Ariananda (2018) bahwa sikap kedisiplinan penting dan harus dimiliki oleh setiap siswa. Disiplin membantu siswa dalam proses pembentukan sikap, perilaku dan akan mengatur seorang siswa sukses dalam belajar.

Pada indikator aktif dalam belajar menunjukan skor nilai 62,5 berada pada kriteria baik. Menurut Suryo Subroto (2010) aktif dalam belajar bila terdapat ciri-ciri yaitu siswa membuat sesuatu untuk memahami materi pelajaran, pengetahuan dipelajari, dialami dan ditemukan oleh siswa, siswa mengkomunikasikan hasil pikirannya. Dalvi (Rosida,2019) mengatakan pembelajaran aktif sebagai suatu pendekatan dalam pembelajaran yang bermuara pada belajar mandiri, maka kegiatan belajar mengajar yang dirancang harus mampu melibatkan siswa secara aktif. Sehingga siswa tidak hanya sekedar mendengarkan informasi dari guru, akan tetapi juga melihat apa yang dijelaskan oleh guru dan kegiatan siswa yang terakhir adalah melakukan atau mencobanya secara langsung.

Upaya guru dalam mengembangkan kemandirian belajar siswa tersebut dengan cara memberikan aturan yang harus mereka laksanakan setiap harinya. Membiasakan siswa untuk melakukan segala sesuatu dengan berusaha sendiri tanpa bantuan guru. Dari pembiasaan tersebut maka menjadikan karakter kemandirian belajar siswa yang melekat erat dalam diri siswa sehingga akan mempermudah siswa dalam melaksanakan pembelajaran tematik sehingga tercapainya tujuan pembelajaran yang diharapkan.

\section{SIMPULAN DAN SARAN}

Berdasarkan hasil penelitian yang didapat melalui observasi dan angket dapat disimpulkan bahwa kemandirian belajar siswa kelas III di SDN Karang Jalak 1 berkembang dengan baik dengan rentang nilai 68,3. Kemandirian belajar yang diukur meliputi percaya diri, bertanggung jawab, mampu bekerja sendiri, mampu mengambil keputusan, memiliki hasrat bersaing maju, disiplin dan aktif dalam belajar. Ketujuh indikator tersebut berada dalam kriteria baik terkecuali indikator mampu mengambil keputusan masuk dalam kriteria cukup baik. Dengan demikian, mengacu pada hasil penelitian ini guru dapat merancang pola pembelajaran yang dapat meningkatkan sikap kemandirian. 
Fety Tresnaningsih, Dina Pratiwi Dwi Santi, Etty Suminarsih

KEMANDIRIAN BELAJAR SISWA KELAS III SDN KARANG JALAK I DALAM

PEMBELAJARAN TEMATIK

\section{DAFTAR PUSTAKA}

Ariananda, E. S., Hasan, S., \& Rakhman, M. (2014). Pengaruh kedisiplinan siswa di sekolah terhadap prestasi belajar siswa teknik pendingin. Journal of Mechanical Engineering Education, 1(2), 233-238.

Arikunto, S. (2014). Metode penelitian kuantitatif dan kombinasi. Bandung: Alfabeta.

Bakhtiar, B. (2017). Upaya guru dalam menumbuhkan kemandirian belajar siswa di SD Negeri 22 Banda Aceh. Jurnal Ilmiah Mahasiswa Pendidikan Guru Sekolah Dasar, 2(1).

Bunandar, A. E. S. (2016). Analisis kemandirian belajar siswa pada mata pelajaran biologi.

Desmita. (2009). Psikologi perkembangan peserta didik. Bandung: Remaja Rosdakarya.

Fatimah, E. (2006). Perkembangan peserta didik. Bandung: Pustaka Setia.

Hidayah, U., Putrayasa, I. B., \& Martha, I. N. (2016). Konsistensi ki, kd, dan indikator pada evaluasi guru dalam pembelajaran eksposisi berdasarkan kurikulum 2013 siswa kelas X MAN Patas. Jurnal Pendidikan Bahasa dan Sastra Indonesia Undiksha, $5(3)$.

Isnawati, N., \& Samian, S. (2015). Kemandirian belajar ditinjau dari kreativitas belajar dan motivasi belajar mahasiswa. Jurnal pendidikan ilmu sosial, 25(1), 128-144.

Mina, W., \& Vitoria, L. (2017). Upaya Meningkatkan kemandirian belajar siswa melalui lesson study di kelas V SD Negeri Lampageu Aceh Besar. Jurnal Ilmiah Mahasiswa Pendidikan Guru Sekolah Dasar, 2(1).

Rahmawati, D. (2016). Hubungan antara kemandirian belajar dengan hasil belajar siswa SD Negeri Purwoyoso 06 Semarang. Disertasi Doktor, tidak diterbitkan, Universitas Negeri Semarang, Semarang.

Rosida, P., \& Suprihatin, T. (2019). Pengaruh pembelajaran aktif dalam meningkatkan prestasi belajar Fisika pada siswa Kelas 2 SMU. Proyeksi: Jurnal Psikologi, 6(2), 89-102.

Sa'diyah, R. (2017). Pentingnya Melatih Kemandirian Anak. Kordinat Jurnal Komunikasi Antar Perguruan Tinggi Agama Islam, 16(1), 31-46.

Salina , E., \& Thamrin, M. (2014). Faktor-faktor penyebab anak menjadi tidak mandiri pada usia 5-6 tahun di Raudatul Athfal Babussalam. Jurnal pendidikan dan pembelajaran, $3(6)$.

Setyo, P. E. (2017). Pengaruh Kualitas Produk dan Harga Terhadap Kepuasan Konsumen "Best Autoworks". PERFOMA, 1(6), 755-764. 
Sugiyono, P. (2011). Metodologi penelitian kuantitatif kualitatif dan $r \& d$. Bandung: Alfabeta.

Suid \& Syafrina,A. (2017). Analisis kemandirian siswa dalam proses pembelajaran di Kelas III SD Negeri 1 Banda Aceh. Jurnal Pesona Dasar, 1(5), 70-81.

Suryo, S. B. (2008). Proses belajar mengajar di sekolah. Jakarta: Rineka Cipta.

Tasaik, H. L., \& Tuasikal, P. Peran guru dalam meningkatkan kemandirian belajar peserta didik Kelas V SD Inpres Samberpasi. Metodik Didaktik.

Uno, H. B. (2006). Perencanaan pembelajaran. Jakarta: Bumi Aksara. 